\title{
Hyperfunction of Dopaminergic and Serotonergic Neuronal Systems in Mice Lacking the NMDA Receptor $\epsilon 1$ Subunit
}

\author{
Yoshiaki Miyamoto, ${ }^{1}$ Kiyofumi Yamada, ${ }^{1}$ Yukihiro Noda, ${ }^{1}$ Hisashi Mori, ${ }^{2}$ Masayoshi Mishina, ${ }^{2}$ and \\ Toshitaka Nabeshima ${ }^{1}$ \\ ${ }^{1}$ Department of Neuropsychopharmacology and Hospital Pharmacy, Nagoya University Graduate School of Medicine, \\ Nagoya 466-8560, Japan, and 2Department of Molecular Neurobiology and Pharmacology, School of Medicine, \\ University of Tokyo, Tokyo 113-0033, Japan
}

NMDA receptors, an ionotropic subtype of glutamate receptors (GluRs) forming high $\mathrm{Ca}^{2+}$-permeable cation channels, are composed by assembly of the GluR $\zeta$ subunit (NR1) with any one of four GluR $\epsilon$ subunits (GluR $\epsilon 1-4$; NR2A-D). In the present study, we investigated neuronal functions in mice lacking the GluR $\epsilon 1$ subunit. GluR $\epsilon 1$ mutant mice exhibited a malfunction of NMDA receptors, as evidenced by alterations of $\left[{ }^{3} \mathrm{H}\right] \mathrm{MK}-801$ binding as well as ${ }^{45} \mathrm{Ca}^{2+}$ uptake through the NMDA receptors. A postmortem brain analysis revealed that both dopamine and serotonin metabolism were increased in the frontal cortex and striatum of GluR $\epsilon 1$ mutant mice. The NMDA-stimulated $\left[{ }^{3} \mathrm{H}\right] \mathrm{do}-$ pamine release from the striatum was increased, whereas $\left[{ }^{3} \mathrm{H}\right] \mathrm{GABA}$ release was markedly diminished in GluR $\epsilon 1$ mutant

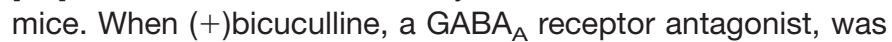
added to the superfusion buffer, NMDA-stimulated $\left[{ }^{3} \mathrm{H}\right]$ dopamine release was significantly increased in wild-type, but not in the mutant mice. GluR $\epsilon 1$ mutant mice exhibited an increased spontaneous locomotor activity in a novel environment and an impairment of latent learning in a water-finding task. Hyperlocomotion in GluR $\epsilon 1$ mutant mice was attenuated by treatment with haloperidol and risperidone, both of which are clinically used antipsychotic drugs, at doses that had no effect in wildtype mice. These findings provide evidence that NMDA receptors are involved in the regulation of behavior through the modulation of dopaminergic and serotonergic neuronal systems. In addition, our findings suggest that GluR $\epsilon 1$ mutant mice are useful as an animal model of psychosis that is associated with NMDA receptor malfunction and hyperfunction of dopaminergic and serotonergic neuronal systems.

Key words: NMDA receptor; GluRe1 subunit; dopaminergic neuronal system; serotonergic neuronal system; hyperlocomotion; schizophrenia
NMDA receptors, a subtype of glutamate receptors (GluRs), play an important role in excitatory neurotransmission, synaptic plasticity, and brain development. They are inherent ligand-gated cation channels with high $\mathrm{Ca}^{2+}$ permeability, which are composed by assembly of the GluR $\zeta$ subunit (NR1) with any one of four GluR $\epsilon$ subunits (GluR $\epsilon 1-4$; NR2A-D). Although the GluR $\zeta$ subunit exists in the brain at all developmental stages, GluRe subunits are expressed in distinct temporal and spatial patterns (Mayer and Westbrook, 1987; Hollmann and Heinemann, 1994; Nakanishi and Masu, 1994).

The diverse functions of NMDA receptor subunits have been demonstrated in mice lacking particular subunits by a genetargeting recombination technique. GluR $\zeta$ mutant mice showed a deficit of all NMDA receptors and perinatal death (Forrest et al., 1994; Li et al., 1994), suggesting that the GluR $\zeta$ subunit is an essential molecule in NMDA receptors and in brain development. Perinatal death was also found in GluR $\epsilon 2$ mutant mice

\footnotetext{
Received May 24, 2000; revised Oct. 30, 2000; accepted Nov. 3, 2000.

This work was supported in part by a Grant-in-Aid for Scientific Research (10044260) and COE Research from the Ministry of Education, Science, Sports, and Culture of Japan, by the Health Sciences Research Grants for Research on Pharmaceutical and Medical Safety from the Ministry of Health and Welfare of Japan, and by Special Coordination Funds for Promoting Science and Technology, TargetOriented Brain Science Research Program from the Ministry of Science and Technology of Japan.

Correspondence should be addressed to Dr. Toshitaka Nabeshima, Department of Neuropsychopharmacology and Hospital Pharmacy, Nagoya University Graduate School of Medicine, 65 Tsuruma-cho, Showa-ku, Nagoya 466-8560, Japan. E-mail: tnabeshi@med.nagoya-u.ac.jp.

Copyright (C) 2001 Society for Neuroscience $\quad 0270-6474 / 01 / 210750-08 \$ 15.00 / 0$
}

(Kutsuwada et al., 1996) but not in GluRe4 mutant mice that showed a reduced spontaneous activity (Ikeda et al., 1995). Mice lacking postnatal GluR $\epsilon 1$ or GluR $\epsilon 3$ are viable: impairments of hippocampal long-term potentiation (LTP) and spatial learning were observed in GluR $\epsilon 1$ mutant mice (Sakimura et al., 1995), whereas GluRe3 mutant mice exhibited no deficiencies (Ebralidze et al., 1996). These findings suggest that GluR $\epsilon$ subunits are major determinants of the functional roles of NMDA receptors.

Pharmacological studies have revealed that blockade of NMDA receptors in vivo causes behavioral abnormalities accompanied by the functional alteration of monoaminergic neuronal systems. For example, noncompetitive NMDA receptor antagonist MK-801 or phencyclidine (PCP) induces characteristic behavioral syndromes in animals, including hyperlocomotion and stereotypy, which are accompanied by an increase in dopaminergic and serotonergic neuronal activities in various brain regions (Hiramatsu et al., 1989; Loscher et al., 1991). Genetic evidence has recently been obtained in mice with reduced GluR $\zeta$ subunit (Mohn et al., 1999). The mutant mice display behavioral abnormalities, which are similar to those observed in rodents treated with NMDA receptor antagonists. The behavioral alterations in the mutant mice were ameliorated by treatment with haloperidol or clozapine, antipsychotic drugs that block dopaminergic and serotonergic receptors. Accordingly, the mutant mice with reduced GluR $\zeta$ subunit are proposed as a new animal model for schizophrenia, which has been hypothesized to be associated with NMDA receptor dysfunction (Javitt and Zukin, 1991; Tamminga, 1998) and the 
hyperfunction of dopaminergic and serotonergic neuronal systems (Seeman et al., 1976; Meltzer, 1991).

In the present study, we investigated the alteration of neuronal functions in mice lacking the GluR $\epsilon 1$ subunit. The $\left[{ }^{3} \mathrm{H}\right] \mathrm{MK}-801$ binding and the ${ }^{45} \mathrm{Ca}^{2+}$ uptake through the NMDA receptors were measured to examine the functional alterations of NMDA receptors in GluR $\epsilon 1$ mutant mice. To demonstrate the modulatory effect of NMDA receptors on monoaminergic neuronal systems, monoamine metabolism was evaluated from the tissue contents of monoamines and their metabolites. The NMDAstimulated $\left[{ }^{3} \mathrm{H}\right]$ dopamine and $\left[{ }^{14} \mathrm{C}\right]$ serotonin releases were also measured in GluR $\epsilon 1$ mutant mice. Finally, we assessed the behavioral alteration and the effects of neuroleptics on this alteration in GluR $\epsilon 1$ mutant mice.

\section{MATERIALS AND METHODS}

Animals. Mutant mice lacking the GluR $\epsilon 1$ subunit of NMDA receptors were provided by Sakimura et al. (1995). The homozygous GluR $\epsilon 1$ mutant mice (-/-; 3-months-old) and the wild-type mice $(+/+$; 3 -months-old) used in this study were obtained by crossing F13 heterozygous GluR $\epsilon 1$ mutant mice $(+/-)$ having a $99.99 \%$ pure C57BL/6 genetic background. The genotypes of mice were determined by tail biopsy and PCR, using primers E1P1, 5'-TCTGGGGCCTGGTCTTCAACAATTCTGTGC-3' (the nucleotide residues 1766-1795 of GluR $\epsilon 1$ cDNA), E1P2, 5'-CTTCTTGTCACTGAGGCCAGTCACTTGGTC-3' (complementary to the residues 1921-1950), and NeoP1, 5'GCCTGCTTGCCGAATATCATGGTGGAAAAT-3'. The animals were housed in plastic cages and were kept in a regulated environment $\left(24 \pm 1{ }^{\circ} \mathrm{C}, 50 \pm 5 \%\right.$ humidity), with a $12 \mathrm{hr}$ light/dark cycle (lights on at 9:00 A.M.). Food and tap water were available ad libitum. All experiments were performed in accordance with the Guidelines for Animal Experiments of the Nagoya University School of Medicine. The procedures involving animals and their care were conducted in conformity with the international guidelines Principles of Laboratory Animal Care (National Institutes of Health publication 85-23, revised 1985).

$\left[{ }^{3} H\right] M K-801$ binding. The GluR $\epsilon 1$ mutant mice and the wild-type mice were killed by decapitation, and brains were quickly removed and placed on an ice-cold glass plate. The forebrain (minus the cerebellum and brainstem) was rapidly dissected out, frozen, and stored in a deep freezer at $-80^{\circ} \mathrm{C}$ until assayed. $\left[{ }^{3} \mathrm{H}\right] \mathrm{MK}-801$ binding was measured as described previously (Yoneda and Ogita, 1989, 1991), with a minor modification. Briefly, frozen samples were thawed at room temperature and homogenized in 40 volumes of $50 \mathrm{~mm}$ Tris-acetate buffer, $\mathrm{pH} 7.4$, containing 1 mM EDTA using a Physcotron homogenizer. All further procedures were performed at $4^{\circ} \mathrm{C}$. The homogenates were centrifuged at $40,000 \times$ $g$ for $30 \mathrm{~min}$, and resultant pellets were washed three times with the same volume of $50 \mathrm{~mm}$ Tris-acetate buffer, $\mathrm{pH}$ 7.4. The final pellets were suspended in 30 volumes of $0.32 \mathrm{M}$ sucrose, and the suspensions were frozen at $-80^{\circ} \mathrm{C}$ for no longer than 1 week until use. On the day of the experiments, the frozen suspensions were thawed at room temperature and treated with $0.08 \%$ Triton $\mathrm{X}-100$ at $4^{\circ} \mathrm{C}$ (an approximate protein concentration of $0.32 \mathrm{mg} / \mathrm{ml}$ ) for $10 \mathrm{~min}$ with gentle stirring. The treatment was terminated by centrifugation at $40,000 \times g$ for $30 \mathrm{~min}$, and pellets were washed five times with 40 volumes of $50 \mathrm{~mm}$ Tris-acetate buffer, $\mathrm{pH} 7.4$, followed by centrifugation at $40,000 \times g$ for $30 \mathrm{~min}$. For determination of $\left[{ }^{3} \mathrm{H}\right] \mathrm{MK}-801$ binding, an aliquot $(0.3 \mathrm{mg}$ of protein) of the membrane preparations was incubated, in the presence or absence of glutamate $(10 \mu \mathrm{M})$, glycine $(10 \mu \mathrm{M})$, and spermidine $(1 \mathrm{mM})$, with $5 \mathrm{nM}$ $(+)\left[3-{ }^{3} \mathrm{H}\right] \mathrm{MK}-801$ (22.5 Ci/mmol; NEN Life Science Products, Boston, MA) in a total volume of $0.5 \mathrm{ml}$ of $50 \mathrm{~mm}$ Tris-acetate buffer, $\mathrm{pH} 7.4$, at $30^{\circ} \mathrm{C}$ for $16 \mathrm{hr}$. The incubation was terminated by the addition of $3 \mathrm{ml}$ of ice-cold $50 \mathrm{~mm}$ Tris-acetate buffer and subsequent filtration through a Whatman GF/B glass filter under a constant vacuum. The filter was rinsed with the same volume of ice-cold $50 \mathrm{~mm}$ Tris-acetate buffer three times within $10 \mathrm{sec}$. Radioactivity retained on the filter was measured by liquid scintillation spectrophotometry, at a counting efficiency of 57$59 \%$. Nonspecific binding was defined with $0.1 \mathrm{~mm}$ cold $(+) \mathrm{MK}-801$ (Sigma, St. Louis, MO), and the specific binding accounted for $>60 \%$ of the total binding found in the absence of cold (+)MK-801.

${ }^{45} \mathrm{Ca}^{2+}$ uptake. The GluR $\epsilon 1$ mutant mice and the wild-type mice were killed by decapitation, the brains were quickly removed, and the forebrain was dissected out on an ice-cold glass plate. The forebrains were homogenized in 20 volumes of ice-cold $0.32 \mathrm{M}$ sucrose at $4^{\circ} \mathrm{C}$ in a Teflon glass homogenizer. All further procedures were performed at $4^{\circ} \mathrm{C}$. The homogenates were centrifuged at $1000 \times g$ for $10 \mathrm{~min}$. The supernatants were collected and then diluted 1:1 with basal buffer of the following composition (in $\mathrm{mm}$ ): $135 \mathrm{NaCl}, 5 \mathrm{KCl}, 1 \mathrm{CaCl}_{2}$, and $10 \mathrm{HEPES}$, $\mathrm{pH}$-adjusted to 7.4 with Tris base, and centrifuged at $10,000 \times g$ for 15 min. The pellets were resuspended in basal buffer and used for the ${ }^{45} \mathrm{Ca}^{2+}$ uptake assay. The synaptosome suspension $(0.5 \mathrm{mg}$ of protein $)$ was preincubated in a total volume of $450 \mu \mathrm{l}$ of basal buffer, in the presence or absence of $(+) \mathrm{MK}-801(100 \mu \mathrm{M})$, at $37^{\circ} \mathrm{C}$ for $10 \mathrm{~min}$. The ${ }^{45} \mathrm{Ca}^{2+}$ uptake assay was initiated by adding $50 \mu$ l of prewarmed basal buffer containing $1 \mu \mathrm{Ci} / \mathrm{ml}{ }^{45} \mathrm{CaCl}_{2}(18.1 \mathrm{mCi} / \mathrm{mg}$; NEN Life Science Products), in the presence or absence of NMDA $(100 \mu \mathrm{M})$, glycine (10 $\mu \mathrm{M})$, and spermidine $(1 \mathrm{mM})$ or high $\mathrm{K}^{+}(45 \mathrm{mM}$; isomolar replacement of $\mathrm{NaCl}$ with $\mathrm{KCl}$ ). The reaction was terminated after 5 min by adding $3 \mathrm{ml}$ of ice-cold basal buffer. The mixture was rapidly filtered under vacuum over Whatman $\mathrm{GF} / \mathrm{B}$ glass filters, and the filters were rinsed twice with $3 \mathrm{ml}$ of basal buffer. The radioactivity was determined by liquid scintillation spectrophotometry at a counting efficiency of $90 \%$. $\mathrm{Ca}^{2+}$ uptake was defined by subtracting the uptake at $4^{\circ} \mathrm{C}$.

Monoamine metabolism. The GluR $\epsilon 1$ mutant mice and the wild-type mice were killed by focused microwave irradiation for $1.5 \mathrm{sec}$ at $5 \mathrm{~kW}$, the brains were quickly removed, and the prefrontal cortex, striatum, hippocampus, and thalamus were dissected out on an ice-cold glass plate according to the method of Glowinski and Iversen (1966). Each brain region was rapidly frozen and stored in a deep freezer at $-80^{\circ} \mathrm{C}$ until assayed. The contents of monoamines and their metabolites were determined using an HPLC system with an electrochemical detector (Eicom, Kyoto, Japan), as described by Noda et al. (1998). Briefly, each frozen brain sample was weighed and homogenized with an ultrasonic processor in $350 \mu \mathrm{l}$ of $0.2 \mathrm{M}$ perchloric acid containing isoproterenol as an internal standard. The homogenates were placed in ice for $30 \mathrm{~min}$ and centrifuged at $20,000 \times g$ for $15 \mathrm{~min}$ at $4^{\circ} \mathrm{C}$. The supernatants were mixed with $1 \mathrm{M}$ sodium acetate to adjust the $\mathrm{pH}$ to 3.0 and injected into an HPLC system equipped with a reversed-phase ODS column (Eicompak MA-5 ODS; $4.6 \times 150 \mathrm{~mm}$; Eicom) and an electrochemical detector. The column temperature was maintained at $25^{\circ} \mathrm{C}$, and the detector potential was set at $+750 \mathrm{mV}$. The mobile phase was $0.1 \mathrm{M}$ citric acid and $0.1 \mathrm{M}$ sodium acetate, $\mathrm{pH} 3.6$, containing $14 \%$ methanol, $180 \mathrm{mg} / 1$ sodium-Loctanesulfonate and $5 \mathrm{mg} / \mathrm{l}$ EDTA, and the flow rate was set at $1 \mathrm{ml} / \mathrm{min}$. The turnover of monoamines was calculated from the content of each monoamine and their metabolites.

$\left[{ }^{3} \mathrm{H}\right]$ Dopamine, $\left[{ }^{14} \mathrm{C}\right]$ serotonin, and $\left[{ }^{3} \mathrm{H}\right] \mathrm{GABA}$ release. The frontal cortex and striatum in the GluR $\epsilon 1$ mutant and the wild-type mice were dissected and sliced in two directions at a thickness of $300 \mu \mathrm{m}$ in a McIlwain tissue chopper (Yamada et al., 1993). The cortical and striatal slices were incubated at $37^{\circ} \mathrm{C}$ for $30 \mathrm{~min}$ in $2.5 \mathrm{ml}$ of Krebs'-Ringer's solution buffer containing $1 \mu \mathrm{M}\left[{ }^{3} \mathrm{H}\right]$ dopamine $(60.0 \mathrm{Ci} / \mathrm{mmol}$; NEN Life Science Products), $1 \mu \mathrm{M}\left[{ }^{14} \mathrm{C}\right]$ serotonin $(52.3 \mathrm{mCi} / \mathrm{mmol}$; NEN Life Science Products), and $10 \mu \mathrm{M}$ pargyline (Sigma). For $\left[{ }^{3} \mathrm{H}\right]$ GABA release, the striatal slices were incubated in Krebs'-Ringer's solution buffer containing $1 \mu \mathrm{M}\left[{ }^{3} \mathrm{H}\right] \mathrm{GABA}(36.2 \mathrm{Ci} / \mathrm{mmol}$; NEN Life Science Products) and $100 \mu \mathrm{M}$ amino-oxyacetic acid (Sigma). The composition of the Krebs'-Ringer's solution buffer was (in mM): $125 \mathrm{NaCl}, 4.8 \mathrm{KCl}, 25$ $\mathrm{NaHCO}_{3}, 1.2 \mathrm{KH}_{2} \mathrm{PO}_{4}, 1.2 \mathrm{CaCl}_{2}, 10$ glucose, and 0.57 ascorbic acid, gassed with $95 \% \mathrm{O}_{2}$ and $5 \% \mathrm{CO}_{2}$. After three washes, the cortical and striatal slices were transferred to superfusion chambers and superfused with Krebs'-Ringer's solution buffer at a rate of $0.5 \mathrm{ml} / \mathrm{min}$. After $60 \mathrm{~min}$ of superfusion $(\mathrm{t}=60 \mathrm{~min}), 25$ successive $2 \mathrm{~min}$ fractions were collected $(t=60 \mathrm{~min}$ to $\mathrm{t}=110 \mathrm{~min})$. The cortical and striatal slices were exposed to two separate 2 min stimuli with Krebs'-Ringer's solution buffer containing high $\mathrm{K}^{+}(25 \mathrm{~mm}$; isomolar replacement of $\mathrm{NaCl}$ with $\mathrm{KCl})$ starting at $t=70 \mathrm{~min}$ and Krebs'-Ringer's solution buffer containing NMDA $(100 \mu \mathrm{M})$ starting at $t=90 \mathrm{~min}$. After the superfusion, the radioactive material remaining in the tissue slices was extracted with 0.1 $\mathrm{M} \mathrm{HCl}$. The radioactivity was then determined by liquid scintillation spectrophotometry, followed by the fractional efflux rate of each fraction.

The NMDA-stimulated $\left[{ }^{3} \mathrm{H}\right]$ dopamine release from striatal slices was also measured in the presence of $(+)$ bicuculline, a $\mathrm{GABA}_{\mathrm{A}}$ receptor antagonist. The $\left[{ }^{3} \mathrm{H}\right]$ dopamine-labeled striatal slices were superfused with Krebs'-Ringer's solution buffer containing $10 \mu \mathrm{M}$ (+)bicuculline (Sigma) until the end of the experiment. After $60 \mathrm{~min}$ of superfusion, the 


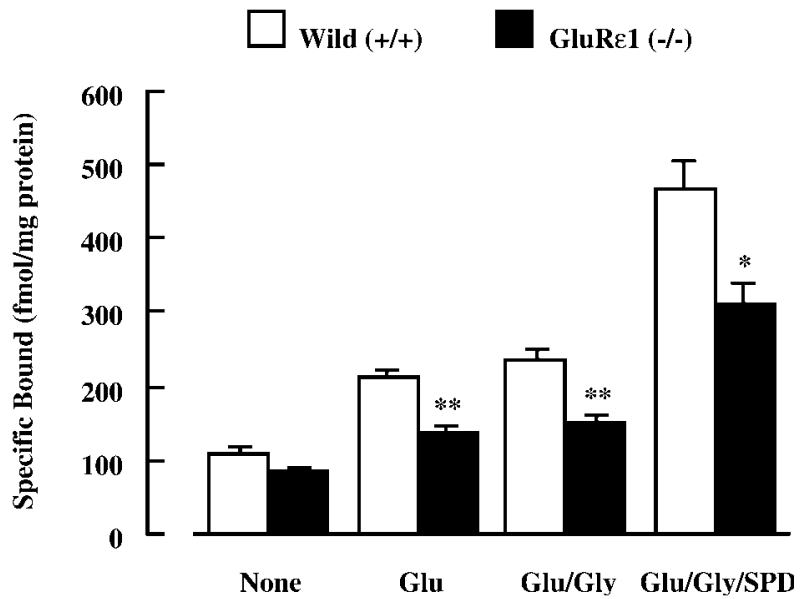

Figure 1. $\left[{ }^{3} \mathrm{H}\right] \mathrm{MK}-801$ binding in forebrain synaptic membranes of GluR $\epsilon 1$ mutant mice. Triton-treated forebrain synaptic membranes were incubated with $5 \mathrm{nM}\left[{ }^{3} \mathrm{H}\right] \mathrm{MK}-801$ at $30^{\circ} \mathrm{C}$ for $16 \mathrm{hr}$, in the presence or absence of $10 \mu \mathrm{M}$ glutamate (Glu), Glu plus $10 \mu \mathrm{M}$ glycine (Gly), or Glu plus Gly plus $1 \mathrm{~mm}$ spermidine $(S P D)$. Each column represents the mean $\pm \operatorname{SEM}(n=4) .{ }^{*} p<0.05 ; * * p<0.01$ versus wild $(+/+)$.

striatal slices were stimulated by NMDA $(100 \mu \mathrm{M})$ for 2 min starting at $t=90 \mathrm{~min}$, as described above.

Behavioral analyses. To measure locomotor activity in a novel environment, a mouse was placed in a transparent acrylic cage with a black frosting Plexiglas floor $(45 \times 26 \times 40 \mathrm{~cm})$, and locomotion and rearing were measured every $5 \mathrm{~min}$ for $120 \mathrm{~min}$ using digital counters with infrared sensors (Scanet SV-10; Toyo Sangyo, Toyama, Japan).

The water-finding task was performed as described previously (Ichihara et al., 1989, 1993; Nabeshima and Ichihara, 1993). Briefly, the apparatus consisted of an open field $(30 \times 50 \times 15 \mathrm{~cm})$ with an alcove $(10 \times 10 \times 10 \mathrm{~cm})$ in the middle of one of the long walls of the enclosure. The inside was painted gray, and the floor of the open field was divided into 15 identical squares with black lines. A drinking tube, identical to that used in the home cage, was inserted into the center of the alcove ceiling with its tip $5 \mathrm{~cm}$ (in the training trial) or $7 \mathrm{~cm}$ (in the test trial) above the floor. The task consisted of two trials; a training trial (the 1st day) and a test trial (the 2nd day). In the training trial, a mouse not deprived of water was placed in one corner of the open field and allowed to freely explore the training apparatus for $3 \mathrm{~min}$. During this time, the frequency of touching, sniffing, or licking of the drinking tube in the alcove (number of approaches) was recorded. It should be noted that water was not delivered from the drinking tube in the training trial. Animals that did not begin exploring within $3 \mathrm{~min}$ or did not make contact with the drinking tube during exploration were omitted from the test trial. One of 13 GluR $\epsilon 1$ mutant mice tested was excluded because of this criterion, whereas none of wild-type mice $(n=12)$ were excluded. The mouse was immediately returned to the home cage after the training trial and was deprived of water for $24 \mathrm{hr}$ before the test trial. Nontrained mice were prepared for comparison with the trained mice in terms of their ability to find the water source in the same apparatus. In the test trial, the trained mouse or a nontrained mouse was placed in the same corner of the test apparatus. The time until the mouse moved out of the corner and the time until the mouse entered the alcove were measured as the starting latency and the entering latency, respectively. In addition, the time between entering the alcove and drinking the water (finding latency) was measured. Thus, latent learning was assessed by recording the number of approaches in the training trial and starting, entering, and finding latencies in the test trial.

Drugs. Haloperidol was purchased from Sigma. Risperidone was supplied by Janssen Kyowa (Tokyo, Japan). Haloperidol and risperidone were dissolved in distilled water containing two equivalent volumes of tartaric acid. Haloperidol $(0.003$ or $0.01 \mathrm{mg} / \mathrm{kg}$, p.o.) or risperidone $(0.01$ or $0.03 \mathrm{mg} / \mathrm{kg}$, p.o.) was administered $60 \mathrm{~min}$ before the measurement of locomotor activity in a novel environment.

Statistical analysis. All data were expressed as the mean \pm SEM. Statistical differences between the GluR $\epsilon 1$ mutant and the wild-type mice were determined with Student's $t$ comparison test. In the analysis of locomotion and rearing curves, statistical differences between the
Wild (-MK-801) Wild (+MK-801)

GluRe1 (- MK-801) GluRe1 (+ MK-801)

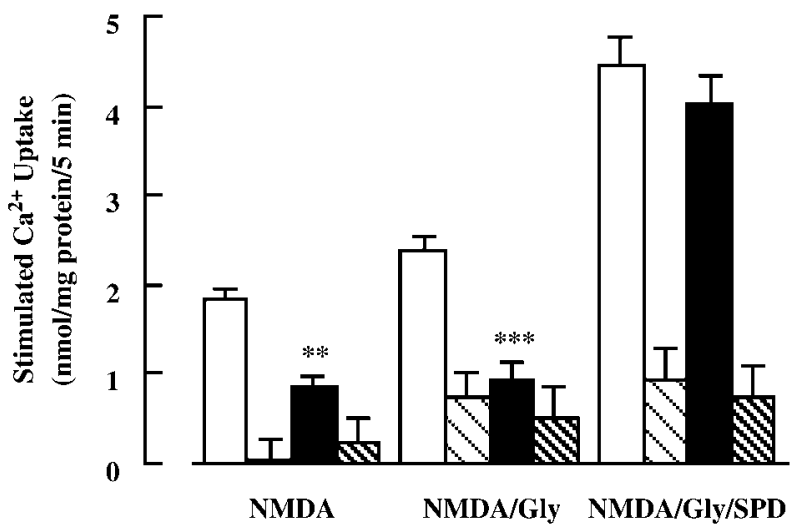

Figure 2. NMDA-stimulated ${ }^{45} \mathrm{Ca}^{2+}$ uptake into forebrain synaptosomes of GluR $\epsilon 1$ mutant mice. The forebrain synaptosomes were preincubated at $37^{\circ} \mathrm{C}$ for $10 \mathrm{~min}$, in the presence or absence of $100 \mu \mathrm{M} \mathrm{MK}-801$. The assay was initiated by adding prewarmed buffer containing $1 \mu \mathrm{Ci} / \mathrm{ml}$ ${ }^{45} \mathrm{CaCl}_{2}$ for $5 \mathrm{~min}$, in the presence of $100 \mu \mathrm{M}$ NMDA, NMDA plus $10 \mu \mathrm{M}$ Gly, or NMDA plus Gly plus $1 \mathrm{~mm}$ SPD. Each column represents the mean \pm SEM $(n=6) .{ }^{* *} p<0.01,{ }^{* *} p<0.001$ versus wild $(-M K-801)$.

GluR $\epsilon 1$ mutant and the wild-type mice were determined by an ANOVA with repeated measures. In the behavioral analysis using pharmacological agents, statistical differences among values for individual groups were determined by ANOVA, followed by the Student-Newmann-Keuls multiple comparisons test when $F$ ratios were significant $(p<0.05)$.

\section{RESULTS}

\section{Function of NMDA receptors in GluR $\epsilon 1$ mutant mice}

A previous study has shown that NMDA receptor channel current and LTP in the hippocampal CA1 region are reduced in GluR $\epsilon 1$ mutant mice (Sakimura et al., 1995). These findings suggest that the targeted disruption of the GluR $\epsilon 1$ subunit gene results in an impairment of NMDA receptor function. To demonstrate the functional alterations of NMDA receptors in GluR $\epsilon 1$ mutant mice, we first performed a radioligand-binding assay using a noncompetitive NMDA receptor antagonist, $\left[{ }^{3} \mathrm{H}\right] \mathrm{MK}-801$ (Fig. 1). The binding of $\left[{ }^{3} \mathrm{H}\right] \mathrm{MK}-801$ was determined in forebrain synaptic membranes treated with Triton $\mathrm{X}-100$ to deplete endogenous amino acids (Yoneda and Ogita, 1989, 1991). There was no difference in the basal specific binding of $\left[{ }^{3} \mathrm{H}\right] \mathrm{MK}-801$ between wild-type and GluR $\epsilon 1$ mutant mice. The specific binding of $\left[{ }^{3} \mathrm{H}\right] \mathrm{MK}-801$ in both wild-type and GluR $\epsilon 1$ mutant mice was markedly increased when the assay was performed in the presence of $10 \mu \mathrm{M}$ glutamate, glutamate plus $10 \mu \mathrm{M}$ glycine, or glutamate plus glycine plus $1 \mathrm{~mm}$ spermidine. Under the stimulated conditions, there was significantly less specific binding of $\left[{ }^{3} \mathrm{H}\right] \mathrm{MK}-801$ in GluR $\epsilon 1$ mutant mice than wild-type mice. The addition of glycine or spermidine alone did not change the $\left[{ }^{3} \mathrm{H}\right] \mathrm{MK}-801$ binding in either of the mice (data not shown).

We next measured ${ }^{45} \mathrm{Ca}^{2+}$ uptake into forebrain synaptosomes through NMDA receptors (Fig. 2). There was no difference in the basal ${ }^{45} \mathrm{Ca}^{2+}$ uptake into synaptosomes between wild-type and GluR $\epsilon 1$ mutant mice, the value being $12.7 \pm 0.1$ and $13.2 \pm 0.2$ $\mathrm{nmol} / \mathrm{mg}$ of protein per $5 \mathrm{~min}$, respectively. When the assay was performed in the presence of $100 \mu \mathrm{M}$ NMDA, NMDA plus $10 \mu \mathrm{M}$ glycine, or NMDA plus glycine plus $1 \mathrm{~mm}$ spermidine, ${ }^{45} \mathrm{Ca}^{2+}$ uptake was increased in both groups. However, ${ }^{45} \mathrm{Ca}^{2+}$ uptake in 
A: Frontal Cortex

\section{B: Striatum}
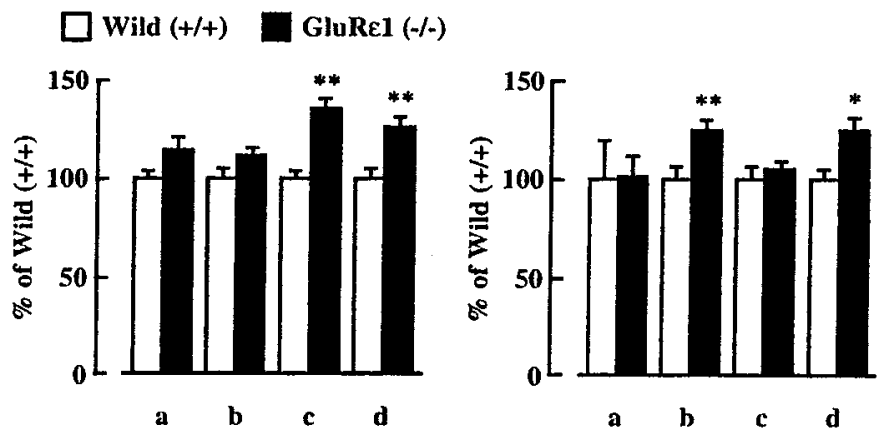

C: Hippocampus

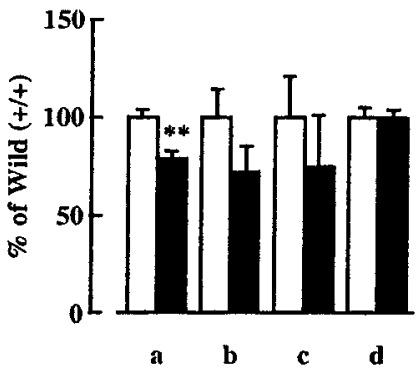

\section{D: Thalamus}

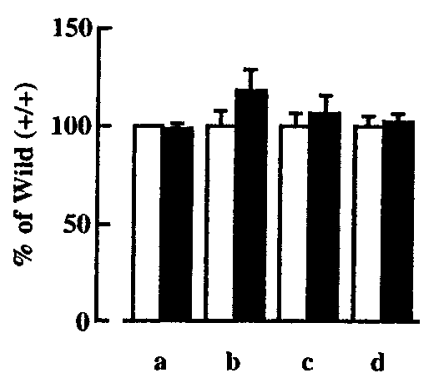

Figure 3. Monoamine metabolism in various brain regions of GluR $\epsilon 1$ mutant mice. The tissue contents of monoamine and its metabolite in various brain regions were measured by HPLC with an electrochemical detector. $a$, MHPG/NE; $b$, DOPAC/DA; $c$, HVA/DA; $d$, 5-HIAA/5HT. Each column represents the mean $\pm \operatorname{SEM}(n=7-8) .{ }^{*} p<0.05$; $* * p<0.01$ versus wild $(+/+)$.

GluR $\epsilon 1$ mutant mice was significantly lower than that in wild-type mice under the stimulated conditions with NMDA or NMDA plus glycine. There was no difference in ${ }^{45} \mathrm{Ca}^{2+}$ uptake between the two groups when the assay was performed in the presence of NMDA, glycine, and spermidine. The NMDA, glycine, and/or spermidine-stimulated ${ }^{45} \mathrm{Ca}^{2+}$ uptake in both groups was antagonized by the addition of $100 \mu \mathrm{M} \mathrm{MK}-801$. In contrast, there was no difference in high $\mathrm{K}^{+}(45 \mathrm{~mm})$-stimulated ${ }^{45} \mathrm{Ca}^{2+}$ uptake between wild-type $(6.5 \pm 0.2 \mathrm{nmol} / \mathrm{mg}$ of protein per $5 \mathrm{~min})$ and GluR $\epsilon 1$ mutant mice $(6.1 \pm 0.3 \mathrm{nmol} / \mathrm{mg}$ of protein per $5 \mathrm{~min})$. These results on the $\left[{ }^{3} \mathrm{H}\right] \mathrm{MK}-801$ binding and the NMDAstimulated ${ }^{45} \mathrm{Ca}^{2+}$ uptake suggest the malfunction of NMDA receptors in GluR $\epsilon 1$ mutant mice.

\section{Monoaminergic neuronal activities in GluRe1 mutant mice}

To investigate whether the targeted disruption of the GluR $\epsilon 1$ subunit gene would affect the function of monoaminergic neuronal systems, monoamine metabolism was assessed from the tissue contents of monoamines and their metabolites in various regions of the brain in GluR $\epsilon 1$ mutant mice. As shown in Figure 3, $A$ and $B$, the ratios of homovanillic acid (HVA) to dopamine (DA) in the frontal cortex and of 3,4-dihydroxyphenylacetic acid (DOPAC) to DA in the striatum were significantly increased to 125.4 and $124.9 \%$, respectively, in GluR $\epsilon 1$ mutant mice compared with in wild-type mice. Moreover, both in the frontal cortex and striatum, the ratio of 5-hydroxyindoleacetic acid (5-HIAA) to serotonin (5-HT) was increased in GluR $\epsilon 1$ mutant mice, to 126.1 and $125.4 \%$, respectively. On the other hand, the ratio of 3-methoxy-4-hydroxyphenylglycol (MHPG) to norepinephrine (NE) was decreased in the hippocampus of GluR $\epsilon 1$ mutant mice (Fig. $3 C$ ). No changes in monoamine metabolism were observed in the thalamus (Fig. $3 D$ ).

We next examined whether $\left[{ }^{3} \mathrm{H}\right] \mathrm{DA}$ and $\left[{ }^{14} \mathrm{C}\right] 5$-HT release induced by the activation of NMDA receptors is altered in GluR $\epsilon 1$ mutant mice (Fig. 4). The $100 \mu \mathrm{M}$ NMDA-stimulated $\left[{ }^{3} \mathrm{H}\right] \mathrm{DA}$ release from striatal slices was significantly increased in GluR $\epsilon 1$ mutant mice, whereas no change in basal release was observed (Fig. 4B). The $\left[{ }^{3} \mathrm{H}\right] \mathrm{DA}$ release from cortical slices of the mutant mice did not differ from that in wild-type mice (data not shown). The NMDA-stimulated $\left[{ }^{14} \mathrm{C}\right] 5-\mathrm{HT}$ release from cortical slices, but not striatal slices (data not shown), showed a tendency to increase in GluR $\epsilon 1$ mutant mice (Fig. $4 A ; p=0.067$ ). There was no difference in high $\mathrm{K}^{+}(25 \mathrm{~mm})$-stimulated $\left[{ }^{3} \mathrm{H}\right] \mathrm{DA}$ and $\left[{ }^{14} \mathrm{C}\right] 5$-HT release between wild-type and GluR $\epsilon 1$ mutant mice (data not shown). To clarify the mechanism of the enhanced NMDA-stimulated $\left[{ }^{3} \mathrm{H}\right] \mathrm{DA}$ release in the striatum of GluR $\epsilon 1$ mutant mice, we examined the role of the GABAergic neuronal system because it has been demonstrated that GABAergic neurons exert an inhibitory effect on the NMDA-evoked DA release in the striatum (Krebs et al., 1993). The NMDA-stimulated $\left[{ }^{3} \mathrm{H}\right] \mathrm{DA}$ release in wild-type mice was significantly increased in

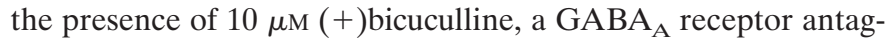
onist, although there was no change in GluR $\epsilon 1$ mutant mice. As a result, NMDA-stimulated $\left[{ }^{3} \mathrm{H}\right] \mathrm{DA}$ release in the presence of $(+)$ bicuculline was significantly reduced in GluR $\epsilon 1$ mutant mice compared with in wild-type mice (Fig. 4C). Accordingly, it is suggested that in wild-type mice, NMDA-stimulated $\left[{ }^{3} \mathrm{H}\right] \mathrm{DA}$ release is tonically suppressed by the concomitant release of GABA, the effect being mediated through $\mathrm{GABA}_{\mathrm{A}}$ receptors. In the mutant mice, NMDA-stimulated GABA release may be decreased because of the malfunction of NMDA receptors, and as a result, the NMDA-stimulated $\left[{ }^{3} \mathrm{H}\right] \mathrm{DA}$ release was not affected by treatment with $(+)$ bicuculline. To prove this, we measured the NMDA-stimulated $\left[{ }^{3} \mathrm{H}\right] \mathrm{GABA}$ release in the striatum. As we expected, the NMDA-stimulated $\left[{ }^{3} \mathrm{H}\right] \mathrm{GABA}$ release from striatal slices was markedly reduced in GluR $\epsilon 1$ mutant mice compared with wild-type mice (Fig. 4D).

These findings suggest that the disruption of the GluR $\epsilon 1$ subunit results in an enhancement of dopaminergic and serotonergic neuronal activities, because of disinhibition of the GABAergic input.

\section{Locomotor activity in GluR $\epsilon \mathbf{1}$ mutant mice}

Locomotor activity in animals is regulated by the monoaminergic neuronal systems, particularly dopaminergic and serotonergic neuronal activities (Giros et al., 1996; Gainetdinov et al., 1999). To clarify the behavioral influences of the altered monoaminergic neuronal functions in GluR $\epsilon 1$ mutant mice, we assessed locomotor activity in a novel environment. The locomotor activity of GluR $\epsilon 1$ mutant mice in a novel environment was recorded by counting the number of infrared sensor crossings for a $120 \mathrm{~min}$ observation period (Fig. 5). During the first 60 min observation period, GluR $\epsilon 1$ mutant mice showed an increase in horizontal (locomotion; Fig. 5A) and vertical (rearing; Fig. 5B) activities compared with wild-type mice [ANOVA analysis with repeated measures; $F_{(1,22)}=3.470, p=0.0002$ (locomotion); $F_{(1,22)}=$ $2.028, p=0.0265$ (rearing)]. However, the increase that occurred during the first $60 \mathrm{~min}$ period was reduced to the level of wildtype mice during the next 60 min period.

To test the involvement of dopaminergic and serotonergic 


\section{A: 5-HT Release in the Frontal Cortex}
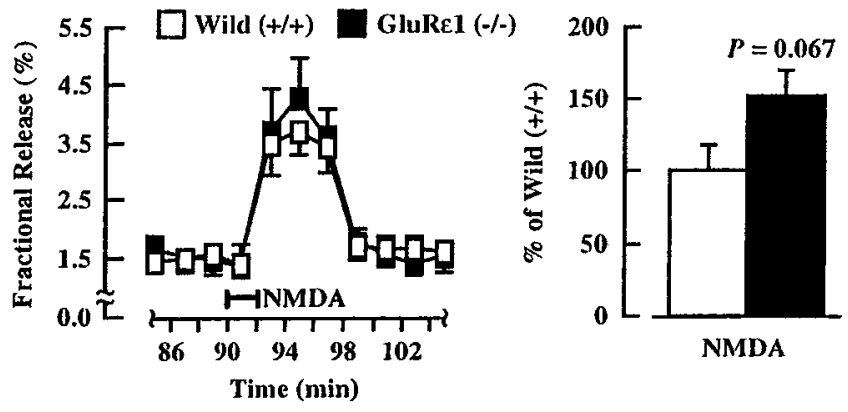

\section{B: DA Release in the Striatum}
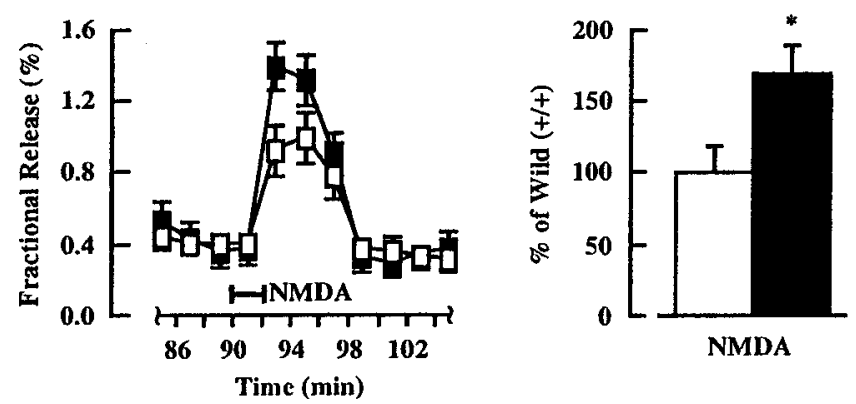

\section{C: DA Release in the Presence of (+)Bicuculline}
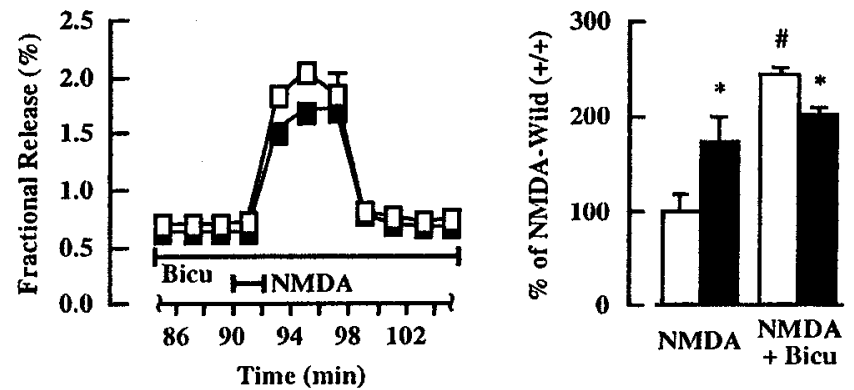

\section{D: GABA Release in the Striatum}
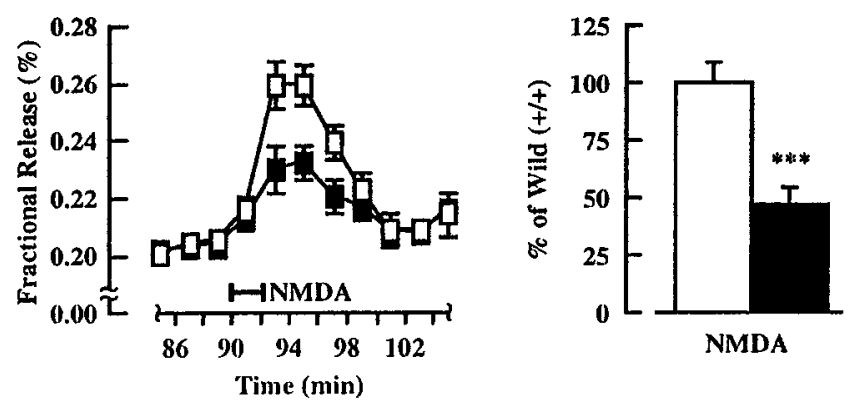

Figure 4. NMDA-stimulated $\left[{ }^{3} \mathrm{H}\right]$ dopamine, $\left[{ }^{14} \mathrm{C}\right]$ serotonin, and $\left[{ }^{3} \mathrm{H}\right] \mathrm{GABA}$ release in GluR $\epsilon 1$ mutant mice. The cortical and striatal slices were incubated with $1 \mu \mathrm{M}\left[{ }^{3} \mathrm{H}\right] \mathrm{DA}, 1 \mu \mathrm{M}\left[{ }^{14} \mathrm{C}\right] 5-\mathrm{HT}$, and $10 \mu \mathrm{M}$ pargyline at $37^{\circ} \mathrm{C}$ for $30 \mathrm{~min}$. For $\left[{ }^{3} \mathrm{H}\right] \mathrm{GABA}$ release, the striatal slices were incubated with $1 \mu \mathrm{M}\left[{ }^{3} \mathrm{H}\right] \mathrm{GABA}$ and $100 \mu \mathrm{M}$ amino-oxyacetic acid. After washes, the cortical and striatal slices were superfused with Krebs'-Ringer's solution buffer at $37^{\circ} \mathrm{C}$ and exposed to $25 \mathrm{mM} \mathrm{KCl}$ at $t=70 \mathrm{~min}$ and then to $100 \mu \mathrm{M} \mathrm{NMDA}$ at $t=90 \mathrm{~min}$ for $2 \mathrm{~min}$. For $\left[{ }^{3} \mathrm{H}\right] \mathrm{DA}$ release in the presence of $(+)$ bicuculline $(\mathrm{Bicu})$, the $\left[{ }^{3} \mathrm{H}\right] \mathrm{DA}-$ labeled striatal slices were superfused with Krebs'-Ringer's solution buffer containing $10 \mu \mathrm{M}(+)$ bicuculline until the end of the experiment. Each column represents the mean $\pm \operatorname{SEM}(n=7-8)$. ${ }^{*} p<0.05$; $* * * p<0.001$ versus corresponding wild $(+/+)$. \#p<0.05 versus NMDA-stimulated $\left[{ }^{3} \mathrm{H}\right] \mathrm{DA}$ release in wild $(+/+)$.
A: Locomotion
Wild $(+/+)$
GluRe1 (-/-)
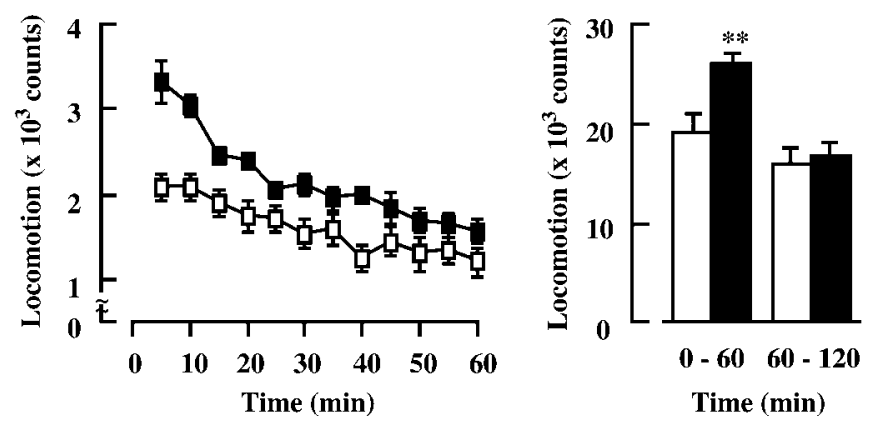

\section{B: Rearing}
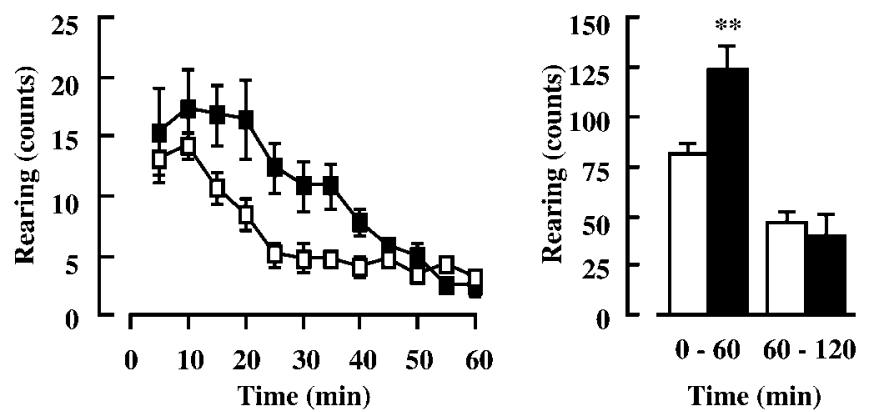

Figure 5. Locomotor activity in a novel environment in GluR $\epsilon 1$ mutant mice. Locomotor activity and the number of rearing events in a novel environment were measured every $5 \mathrm{~min}$ for $120 \mathrm{~min}$. Each column represents the mean $\pm \operatorname{SEM}(n=12)$. An ANOVA with repeated measures revealed a significant difference in locomotion $\left(F_{(1,22)}=3.470\right.$; $p=0.0002)$ and rearing curves $\left(F_{(1,22)}=2.028 ; p=0.0265\right)$. ${ }^{* *} p<0.01$ versus wild $(+/+)$.

neuronal systems in the increased locomotor activity, we examined the effects of a potent DA receptor antagonist, haloperidol, and a DA/5-HT receptor antagonist, risperidone, in GluR $\epsilon 1$ mutant mice (Fig. 6). Both drugs reduced the locomotor activity in wild-type and GluR $\epsilon 1$ mutant mice in a dose-dependent manner. Haloperidol $(0.003 \mathrm{mg} / \mathrm{kg})$ and risperidone $(0.01 \mathrm{mg} / \mathrm{kg})$ ameliorated the hyperlocomotion of GluR $\epsilon 1$ mutant mice, at doses that had no effect in wild-type mice [ANOVA analysis; $F_{(5,43)}=18.806, p<0.0001$ (locomotion-haloperidol); $F_{(5,43)}=$ 8.598, $p<0.0001$ (rearing-haloperidol); $F_{(5,51)}=15.205, p<$ 0.0001 (locomotion-risperidone); $F_{(5,51)}=8.111, p<0.0001$ (rearing-risperidone)]. These results suggest that the increase in dopaminergic and serotonergic neuronal activities contributes to the enhanced locomotor activity in GluR $\epsilon 1$ mutant mice.

\section{Latent learning in GluR $\epsilon 1$ mutant mice}

Previous studies indicated that spatial and contextual learning in GluR $\epsilon 1$ mutant mice is impaired as manifested by performance in the Morris water maze and the contextual fear conditioning tasks (Sakimura et al., 1995; Kiyama et al., 1998). To further explore a possible change in cognitive function in GluR $\epsilon 1$ mutant mice, we examined performance in the water-finding task. Because mice were not reinforced either positively or negatively by water in the training trials of the water-finding task, their performance in the test trial is dependent on latent learning, and selective attention underlies the acquisition of latent learning (Cheal, 1980; Ichihara et al., 1993). There was no significant difference in the number of approaches between wild-type $(n=12 ; 4.9 \pm 0.6)$ and GluR $\epsilon 1$ mutant mice $(n=12 ; 4.1 \pm 0.4)$. Figure 7 shows the performance 


\section{A: Locomotion}

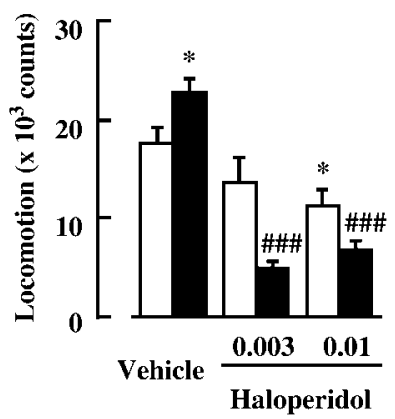

\section{B: Rearing}

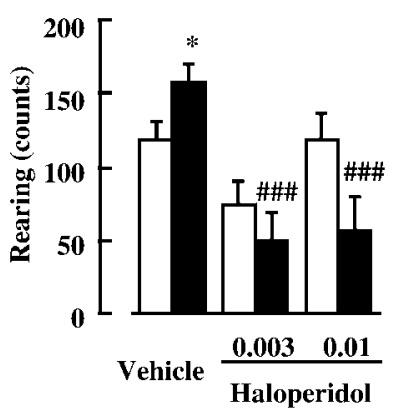

Wild (+/+) GluR\&1 (-/-)
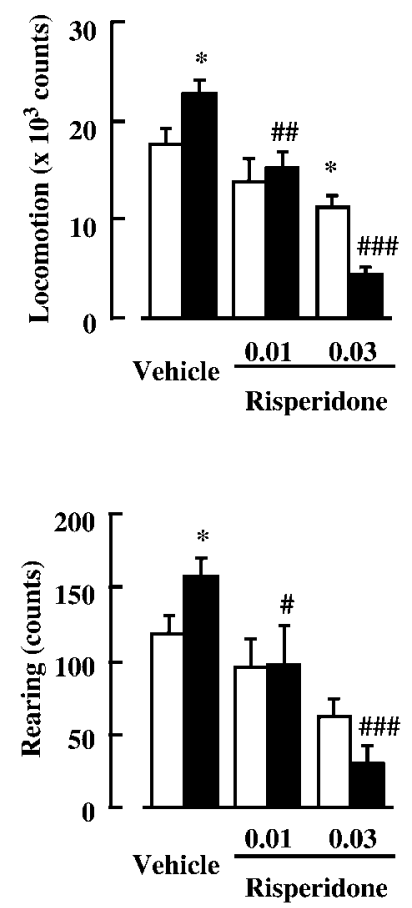

Figure 6. Effects of haloperidol and risperidone on the increased locomotor activity in GluR $\epsilon 1$ mutant mice. Haloperidol $(0.003$ or $0.01 \mathrm{mg} / \mathrm{kg}$, p.o.) or risperidone ( 0.01 or $0.03 \mathrm{mg} / \mathrm{kg}$, p.o.) was administered $60 \mathrm{~min}$ before the measurement of locomotor activity in a novel environment. Each column represents the mean \pm SEM $(n=8-10)$. ANOVA analysis: $F_{(5,43)}=18.806, p<0.0001$ (locomotion-haloperidol); $F_{(5,43)}=8.598, p<$ 0.0001 (rearing-haloperidol); $F_{(5,51)}=15.205, p<0.0001$ (locomotionrisperidone); $F_{(5,51)}=8.111, p<0.0001$ (rearing-risperidone). ${ }^{*} p<0.05$ versus corresponding vehicle-treated wild $(+/+)$. \#p $<0.05$; \#\#p $<0.01$; $\# \# \# p<0.001$ versus corresponding vehicle-treated GluR $\epsilon 1(-/-)$.

in the test trial of the water-finding task in wild-type and GluR $\epsilon 1$ mutant mice. No measurable difference was observed between the two groups of nontrained mice (Fig. $7 A$ ). In wild-type mice that were subjected to the training trial $24 \mathrm{hr}$ earlier (trained wild-type mice), the starting, entering, and finding latencies were shorter than those in the corresponding nontrained wild-type mice. The shortening of starting and entering latencies, but not finding latency, was observed in trained GluR $\epsilon 1$ mutant mice compared with nontrained animals (Fig. 7A). When we compared the performance of trained GluR $\epsilon 1$ mutant mice with that of trained wild-type mice, we found the starting, entering, and finding latencies to be significantly longer in trained GluR $\epsilon 1$ mutant mice than trained wild-type mice (Fig. 7B). Accordingly, these results suggest that the latent learning associated with selective attention to the drinking tube is impaired in GluR $\epsilon 1$ mutant mice.

\section{DISCUSSION}

The NMDA receptor is distinguished by several characteristic properties, including modulation by glycine, activation by polyamines such as spermidine and spermine, inhibition by $\mathrm{Mg}^{2+}$, $\mathrm{Zn}^{2+}$ and specific open-channel blockers (MK-801 and PCP), and high permeability of $\mathrm{Ca}^{2+}$ (Mayer and Westbrook, 1987; Hollmann and Heinemann, 1994; Nakanishi and Masu, 1994). Thus, the NMDA receptor is considered a receptor-channel complex consisting of at least four major domains: (1) a glutamate

(specific exogenous ligand NMDA) recognition domain, (2) a glycine recognition domain insensitive to strychnine, (3) a polyamine recognition domain, and (4) a channel formation domain permeable to $\mathrm{Ca}^{2+}$. In the present study, we investigated the function of NMDA receptors in GluR $\epsilon 1$ mutant mice by examining $\left[{ }^{3} \mathrm{H}\right] \mathrm{MK}-801$ binding and ${ }^{45} \mathrm{Ca}^{2+}$ uptake through the receptors under various conditions. When both assays were conducted in the presence of glutamate (or NMDA), glycine and/or spermidine, partial impairment of NMDA receptor function was evident in the mutant mice.

It has been demonstrated that GluR $\epsilon 1$ mutant mice exhibit a reduction in hippocampal LTP (Sakimura et al., 1995). The reduction may be attributable to a diminution of $\mathrm{Ca}^{2+}$ influx through the NMDA receptors, because $\mathrm{Ca}^{2+}$ influx through NMDA receptors is critical to the induction of hippocampal LTP (Lynch et al., 1983; Malenka et al., 1988). This inference was more directly proved by the malfunction of NMDA receptors in GluR $\epsilon 1$ mutant mice observed in the present study. Furthermore, Kiyama et al. (1998) have reported that although the threshold for LTP induction is increased in GluR $\epsilon 1$ mutant mice, normal LTP formation is seen after a stronger tetanic stimulation. Consistent with the finding, a reduction of ${ }^{45} \mathrm{Ca}^{2+}$ uptake in GluR $\epsilon 1$ mutant mice was not observed any more when NMDA receptors were strongly activated by NMDA, glycine, and spermidine. Accordingly, it is suggested that the disruption of the GluR $\epsilon 1$ subunit results in a reduction, but not the loss, of NMDA receptor function.

The pharmacological blockade of NMDA receptors in vivo causes behavioral abnormalities such as hyperlocomotion and stereotypy and functional alterations of monoaminergic neuronal systems, particularly dopaminergic and serotonergic neuronal systems (Hiramatsu et al., 1989; Loscher et al., 1991). Locomotor activity is mainly regulated by the dopaminergic neuronal system, and the activation of this system induces hyperlocomotion (Giros et al., 1996; Gainetdinov et al., 1999). The serotonergic neuronal system is also involved in the modulation of locomotor activity, being localized downstream of the dopaminergic neuronal system, because serotonergic neurotransmission can modulate behavioral alteration without producing concurrent changes of dopaminergic neurotransmission (Gainetdinov et al., 1999). Activation of the serotonergic neuronal system is inhibitory to hyperlocomotion (Geyer, 1996; Lucki, 1998). Accordingly, it has been considered that the blockade of NMDA receptors in vivo causes hyperlocomotion by either directly or indirectly activating dopaminergic neuronal function (Imperato et al., 1990; Miller and Abercrombie, 1996). In the present study, we demonstrated that GluR $\epsilon 1$ mutant mice with genetically reduced NMDA receptor function exhibited hyperlocomotion, which is associated with an increase in dopaminergic and serotonergic neuronal activities in the frontal cortex and striatum. The increased serotonergic neuronal activity in vivo in GluR $\epsilon 1$ mutant mice may be a result of delicate homeostatic alterations after the increase in dopaminergic neuronal activity to maintain a balance between the neuronal systems for locomotor activity.

We observed an increase in NMDA-stimulated $\left[{ }^{3} \mathrm{H}\right] \mathrm{DA}$ release in the striatum, but not the frontal cortex, of GluR $\epsilon 1$ mutant mice, although DA metabolism was enhanced in both regions in vivo. The NMDA-stimulated $\left[{ }^{14} \mathrm{C}\right] 5-\mathrm{HT}$ release in the frontal cortex and striatum of the mutant mice did not differ from that in wild-type mice, although 5-HT metabolism was enhanced in both regions in vivo. Thus, it is likely that not only direct effects, but also indirect effects, of the reduced NMDA receptor function are 
A

Figure 7. Latent learning in the water-finding task in GluR $\epsilon 1$ mutant mice. The starting, entering, and finding latencies were measured in the test trial $24 \mathrm{hr}$ after the training trial of the water-finding task. The starting, entering, and finding latencies in trained wild-type mice $(+/+)$ were $2.1 \pm 0.3,9.0 \pm 0.8$, and $67.5 \pm 17.9 \mathrm{sec}$, respectively. Each column represents the mean \pm SEM $(n=12) .{ }^{*} p<0.05 ; * * p<0.01$ versus corresponding nontrained group. $\# p<0.05$; $\# \# p<0.01$ versus trained wild $(+/+)$.

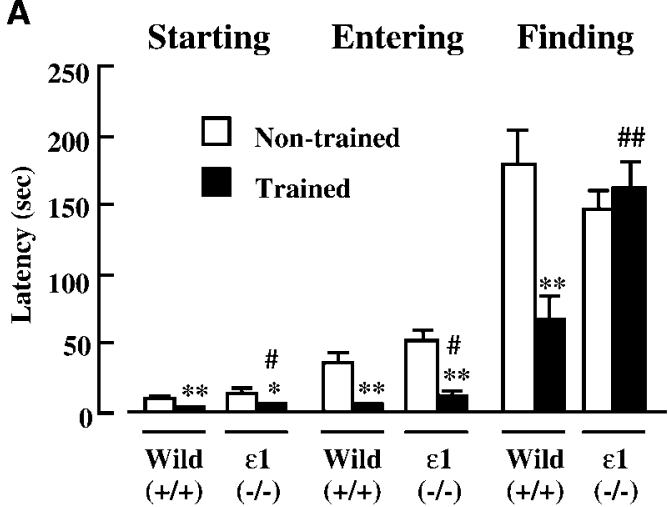

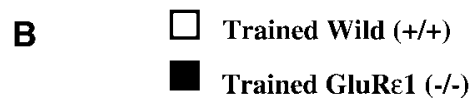

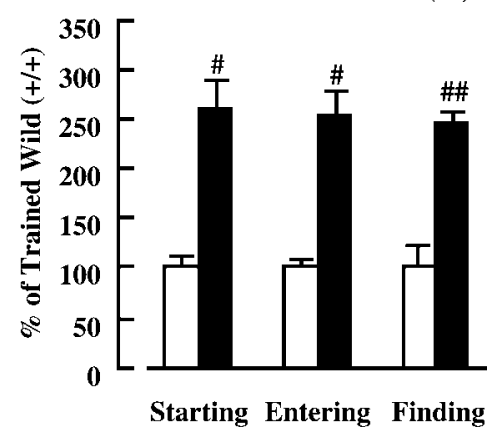

involved in the increased dopaminergic and serotonergic neuronal activity in vivo. We demonstrated in the present study that the enhancement of NMDA-stimulated $\left[{ }^{3} \mathrm{H}\right] \mathrm{DA}$ release in GluR $\epsilon 1$ mutant mice is attributable to the disinhibition of the dopaminergic neuronal system from inhibitory regulation by the GABAergic neuronal system. Alternatively, it has been demonstrated that PCP and its analog ketamine cause an increase in glutamate release and activation of glutamatergic neurotransmission via non-NMDA and metabotropic glutamate receptors. This enhancement of glutamatergic neurotransmission results in an increase in DA release (Moghaddam et al., 1997; Adams and Moghaddam, 1998; Moghaddam and Adams, 1998). Therefore, it is necessary to measure the release of various neurotransmitters in GluR $\epsilon 1$ mutant mice to clarify the neurochemical mechanism that underlies the hyperactivity of dopaminergic and serotonergic neuronal systems.

Schizophrenia is one of the diseases that have been hypothesized to be associated with NMDA receptor dysfunction (Javitt and Zukin, 1991; Tamminga, 1998) and the hyperfunction of dopaminergic and serotonergic neuronal systems (Seeman et al., 1976; Meltzer, 1991). Several lines of evidence suggest that dysfunction of glutamatergic and dopaminergic neuronal mechanisms contributes to the pathophysiology of schizophrenia. For example, PCP produces schizophrenia-like symptoms in healthy people (Luby et al., 1959), and preexisting symptoms in patients with schizophrenia are exacerbated by its psychotomimetic properties (Javitt and Zukin, 1991; Malhotra et al., 1997). Clinical doses of antipsychotic drugs in treating schizophrenia are correlated with their affinities for $\mathrm{D}_{2}$ receptors (Seeman et al., 1976; Leysen et al., 1994). Antipsychotic DA receptor antagonists are also effective in preventing PCP-induced abnormal behavior in animals such as hyperlocomotion and stereotyped behavior (Kitaichi et al., 1994; Noda et al., 1995). Therefore, animals treated with NMDA receptor antagonists have been used as a model for schizophrenia, and the amelioration of hyperlocomotion in this animal model is known as a screening test for the efficacy of antipsychotic drugs (Carlsson and Carlsson, 1990; Corbett et al., 1993, 1995; Moghaddam and Adams, 1998).

In the present study, we examined the effects of haloperidol $\left(\mathrm{D}_{2}\right.$ receptor antagonist) and risperidone $\left(\mathrm{D}_{2}\right.$ and $5-\mathrm{HT}_{2}$ receptor antagonist) on the hyperlocomotion in GluR $\epsilon 1$ mutant mice, because our neurochemical experiments suggested that dopaminergic and serotonergic neuronal activities are increased in the mutant mice. Haloperidol and risperidone are administered to schizophrenic patients as typical and atypical antipsychotic drugs, respectively, the former having marked extrapyramidal side ef- fects (EPS) at effective doses (Hoffman and Donovan, 1995) and the latter being able to suppress psychotic symptoms without EPS (Ereshefsky et al., 1989; Gerlach, 1991). Haloperidol and risperidone were effective in attenuating the hyperlocomotion of GluR $\epsilon 1$ mutant mice at doses that did not affect the locomotor activity in wild-type mice.

GluR $\epsilon 1$ mutant mice also showed an impairment of performance in the test trial of the water-finding task (i.e., an increase of starting, entering, and finding latencies), although their performance in the training trial did not differ from that of wild-type mice. Therefore, it is unlikely that the impairment of the mutant mice is attributable to altered anxiety processes (for example, avoidance of open field). Because the mice were not reinforced either positively or negatively by water in the training trial, their performance in the test trial is dependent on latent learning, and selective attention underlies the acquisition of latent learning (Cheal, 1980; Ichihara et al., 1993). Thus, cognitive function, including latent learning associated with selective attention, spatial learning (Sakimura et al., 1995), and contextual learning (Kiyama et al., 1998), is impaired in GluR $\epsilon 1$ mutant mice. The impairment of latent learning in the mutant mice may be attributable to the increased dopaminergic neuronal activity, because activation of dopaminergic neuronal function by treatment with apomorphine and methamphetamine results in an impairment of performance in the water-finding task (Ichihara et al., 1993; Nabeshima et al., 1994). Moreover, PCP-treated mice, which have been used as a pharmacological animal model for schizophrenia, were impaired in latent learning in the water-finding task (our unpublished observations).

Collectively, GluR $\epsilon 1$ mutant mice exhibit several behavioral abnormalities related to schizophrenia, including hyperlocomotion and cognitive impairment (Schildkraut, 1965; Snyder et al., 1974; Ban et al., 1984). These findings suggest that GluR $\epsilon 1$ mutant mice, which have hypofunction of the glutamatergic system, as well as hyperactivity of the dopaminergic and serotonergic neuronal systems, may be useful as an animal model for schizophrenia. However, further experiments to characterize the behavioral alteration and the effects of neuroleptics on this behavioral alteration are necessary to establish GluR $\epsilon 1$ mutant mice as a new genetic animal model of schizophrenia.

In summary, mice lacking the GluR $\epsilon 1$ subunit display behavioral abnormalities probably caused by the hyperfunction of dopaminergic and serotonergic neuronal systems as a consequence of NMDA receptor malfunction. In addition, our findings suggest that GluR $\epsilon 1$ mutant mice are useful as an animal model of psychosis such as schizophrenia. 


\section{REFERENCES}

Adams B, Moghaddam B (1998) Corticolimbic dopamine neurotransmission is temporally dissociated from the cognitive and locomotor effects of phencyclidine. J Neurosci 18:5545-5554.

Ban TA, Guy W, Wilson WH (1984) Description and distribution of the subtypes of chronic schizophrenia based on Leonhard's classification. Psychiatr Dev 2:179-199.

Carlsson M, Carlsson A (1990) Interactions between glutamatergic and monoaminergic systems within the basal ganglia: implications for schizophrenia and Parkinson's disease. Trends Neurosci 13:272-276.

Cheal ML (1980) Disruption of selective attention by apomorphine, but not amphetamine, in the Mongolian gerbil. Psychopharmacology (Berl) 69:93-100.

Corbett R, Hartman H, Kerman LL, Woods AT, Strupczewski JT, Helsley GC, Conway PC, Dunn RW (1993) Effects of atypical antipsychotic agents on social behavior in rodents. Pharmacol Biochem Behav 45:9-17.

Corbett R, Camacho F, Woods AT, Kerman LL, Fishkin RJ, Brooks K, Dunn RW (1995) Antipsychotic agents antagonize non-competitive $\mathrm{N}$-methyl-D-aspartate antagonist-induced behaviors. Psychopharmacology (Berl) 120:67-74.

Ebralidze AK, Rossi DJ, Tonegawa S, Slater NT (1996) Modification of NMDA receptor channels and synaptic transmission by targeted disruption of the NR2C gene. J Neurosci 16:5014-5025.

Ereshefsky L, Watanabe MD, Tran-Johnson TK (1989) Clozapine: an atypical antipsychotic agent. Clin Pharmacol 8:691-709.

Forrest D, Yuzaki M, Soares HD, Hg L, Luk DC, Sheng M, Stewart CL, Morgan JI, Connor JA, Curran T (1994) Targeted disruption of NMDA receptor 1 gene abolishes NMDA response and results in neonatal death. Neuron 13:325-338.

Gainetdinov RR, Wetsel WC, Jones SR, Levin ED, Jaber M, Caron MG (1999) Role of serotonin in the paradoxical calming effect of psychostimulants on hyperactivity. Science 283:397-401.

Gerlach J (1991) New antipsychotics: classification, efficacy, and adverse effects. Schizophr Bull 17:289-309.

Geyer MA (1996) Serotonergic functions in arousal and motor activity. Behav Brain Res 73:31-35.

Giros B, Jaber M, Jones SR, Wightmann RM, Caron MG (1996) Hyperlocomotion and indifference to cocaine and amphetamine in mice lacking the dopamine transporter. Nature 379:606-612.

Glowinski J, Iversen LL (1966) Regional studies of catecholamines in the rat brain. I. the disposition of $\left[{ }^{3} \mathrm{H}\right]$ norepinephrine, $\left[{ }^{3} \mathrm{H}\right]$ dopamine and $\left[{ }^{3} \mathrm{H}\right]$ dopa in various regions of the brain. J Neurochem 13:655-669.

Hiramatsu M, Cho AK, Nabeshima T (1989) Comparison of the behavioral and biochemical effects of the NMDA receptor antagonists, MK801 and phencyclidine. Eur J Pharmacol 166:359-366.

Hoffman DC, Donovan H (1995) Catalepsy as a rodent model for detecting antipsychotic drugs with extarpyramidal side effect liability. Psychopharmacology (Berl) 120:128-133.

Hollmann M, Heinemann S (1994) Cloned glutamate receptors. Annu Rev Neurosci 17:31-108.

Ichihara K, Nabeshima T, Kameyama T (1989) Differential effects of pimozile and SCH23390 on acquisition of learning in mice. Eur J Pharmacol 164:189-195.

Ichihara K, Nabeshima T, Kameyama T (1993) Dopaminergic agonists impair latent learning in mice: possible modulation by noradrenergic function. J Pharmacol Exp Ther 264:122-128.

Ikeda K, Araki K, Takayama C, Inoue Y, Yagi T, Aizawa S, Mishina M (1995) Reduced spontaneous activity of mice defective in the $\epsilon 4$ subunit of the NMDA receptor channel. Mol Brain Res 33:61-71.

Imperato A, Scrocco MG, Bacchi S, Angelucci L (1990) NMDA receptors and in vivo dopamine release in the nucleus accumbens and caudatus. Eur J Pharmacol 187:555-556.

Javitt DC, Zukin SR (1991) Recent advances in the phencyclidine model of schizophrenia. Am J Psychiatry 148:1301-1308.

Kitaichi K, Yamada K, Hasegawa T, Furukawa H, Nabeshima T (1994) Effects of risperidone on phencyclidine-induced behaviors: comparison with haloperidol and ritanserin. Jpn J Pharmacol 66:181-189.

Kiyama Y, Manabe T, Sakimura K, Kawakami F, Mori H, Mishina M (1998) Increased thresholds for long-term potentiation and contextual learning in mice lacking the NMDA-type glutamate receptor $\epsilon 1$ subunit. J Neurosci 18:6704-6712.

Krebs MO, Kemel ML, Gauchy C, Desban M, Glowinski J (1993) Local GABAergic regulation of the NMDA-evoked release of dopamine is more important in striosomes than in matrix of the rat striatum. Neuroscience 57:249-260.

Kutsuwada T, Sakimura K, Manabe T, Takayama C, Katakura N, Kushiya E, Natsume R, Watanabe M, Inoue Y, Yagi T, Aizawa S, Arakawa M, Takahashi T, Nakamura Y, Mori H, Mishina M (1996) Impairment of suckling response, trigeminal neuronal pattern formation, and hippocampal LTD in NMDA receptor $\epsilon 2$ subunit mutant mice. Neuron 16:333-344.

Leysen JE, Janssen PMF, Megens AAHP, Schotte A (1994) Risperi- done: a novel antipsychotic with balanced serotonin-dopamine antagonism, receptor occupancy profile, and pharmacologic activity. J Clin Psychiatry 55 [Suppl]:5-12.

Li Y, Erzurumlu RS, Chen C, Jhaveri S, Tonegawa S (1994) Whiskerrelated neuronal patterns fail to develop in the trigeminal brainstem nuclei of NMDAR1 knock-out mice. Cell 76:427-437.

Loscher W, Annies R, Honack D (1991) The N-methyl-D-aspartate receptor antagonist MK-801 induces increases in dopamine and serotonin metabolism in several brain regions of rats. Neurosci Lett 128:191-194.

Luby ED, Cohen BD, Rosenbaum F, Gottlieb J, Kelley R (1959) Study of a new schizophrenomimetic drug, Sernyl. Arch Neurol Psychiatry 81:363-369.

Lucki I (1998) The spectrum of behaviors influenced by serotonin. Biol Psychiatry 44:151-162.

Lynch G, Larson J, Kelso S, Barrionuevo G, Schotter F (1983) Intracellular injections of EGTA block induction of hippocampal long-term potentiation. Neuron 305:719-721.

Malenka RC, Kauer JA, Zuker RS, Nicoll RA (1988) Postsynaptic calcium is sufficient for potentiation of hippocampal synaptic transmission. Science 242:81-84.

Malhotra AK, Pinals DA, Adler CM, Elman I, Clifton A, Pickar D, Breier A (1997) Ketamine-induced exacerbation of psychotic symptoms and cognitive impairment in neuroleptic-free schizophrenics. Neuropsychopharmacology 17:141-150.

Mayer ML, Westbrook GL (1987) The physiology of excitatory amino acids in the vertebrate central nervous system. Prog Neurobiol 28:197-276.

Meltzer HY (1991) The mechanism of action of novel antipsychotic drugs. Schizophr Bull 17:263-287.

Miller DW, Abercrombie ED (1996) Effects of MK-801 on spontaneous and amphetamine-stimulated dopamine release in striatum measured with in vivo microdialysis in awake rats. Brain Res Bull 40:57-62.

Moghaddam B, Adams BW (1998) Reversal of phencyclidine effects by a group II metabotropic glutamate receptor agonist in rats. Science 281:1349-1352.

Moghaddam B, Adams B, Verma A, Daly D (1997) Activation of glutamatergic neurotransmission by ketamine: a novel step in the pathway from NMDA receptor blockade to dopaminergic and cognitive disruptions associated with the prefrontal cortex. J Neurosci 17:2921-2927.

Mohn AR, Gainetdinov RR, Caron MG, Koller BH (1999) Mice with reduced NMDA receptor expression display behaviors related to schizophrenia. Cell 98:427-436.

Nabeshima T, Ichihara K (1993) Measurement of dissociation of amnesic and behavioral effects of drugs in mice. In: Paradigms for the study of behavior, methods in neurosciences (Conn PM, ed), Vol 14, pp 217-229. San Diego: Academic.

Nabeshima T, Nakayama S, Ichihara K, Yamada K, Shiotani T, Hasegawa $T$ (1994) Effects of nefiracetam on drug-induced impairment of latent learning in mice in a water finding task. Eur J Pharmacol 255:57-65.

Nakanishi S, Masu M (1994) Molecular diversity and functions of glutamate receptors. Annu Rev Biophys Biomol Struct 23:319-348.

Noda Y, Miyamoto Y, Mamiya T, Kamei H, Furukawa H, Nabeshima T (1998) Involvement of dopaminergic system in phencyclidine-induced place preference in mice pretreated with phencyclidine repeatedly. J Pharmacol Exp Ther 286:44-51.

Noda Y, Yamada K, Furukawa H, Nabeshima T (1995) Enhancement of immobility in a forced swimming test by subacute or repeated treatment with phencyclidine: a new model of schizophrenia. Br J Pharmacol 116:2531-2537.

Sakimura K, Kutsuwada T, Ito I, Manabe T, Takayama C, Kushiya E, Yagi T, Aizawa S, Inoue Y, Sugiyama H, Mishina M (1995) Reduced hippocampal LTP and spatial learning in mice lacking NMDA receptor $\epsilon 1$ subunit. Nature 373:151-155.

Schildkraut JJ (1965) The catecholamine hypothesis of affective disorders: a review of supporting evidence. Am J Psychiatry 122:509-522.

Seeman P, Lee T, Chau-Wong, Wong K (1976) Antipsychotic drug doses and neuroleptic/dopamine receptors. Nature 261:717-719.

Snyder SH, Banerjee SP, Yamamura HI, Greenberg D (1974) Drugs, neurotransmitters, and schizophrenia. Science 184:1243-1253.

Tamminga CA (1998) Schizophrenia and glutamatergic transmission. Crit Rev Neurobiol 12:21-36.

Yamada K, Teraoka T, Morita S, Hasegawa T, Nabeshima T (1993) Neuropharmacological characterization of voltage-sensitive calcium channels: possible existence of neomycin-sensitive, $\omega$-conotoxin GVIA- and dihydropyridine-resistant calcium channels in the rat brain. Jpn J Pharmacol 63:423-432.

Yoneda Y, Ogita K (1989) Labeling of NMDA receptor channels by $\left[{ }^{3} \mathrm{H}\right] \mathrm{MK}-801$ in brain synaptic membranes treated with Triton X-100. Brain Res 499:305-314

Yoneda Y, Ogita K (1991) Heterogeneity of the $N$-methyl-D-aspartate receptor ionophore complex in rat brain, as revealed by ligand binding techniques. J Pharmacol Exp Ther 259:86-96. 